\title{
Current Studies on Hydrology in Japan
}

\section{Sôki YAMAMOTO*}

Taking good opportunity of the Eleventh Pacific Science Congress held in 1966 in Tokyo, S. Yamamoto made a review on the recent hydrologic research by geographers in Japan ${ }^{1)}$. Since then increasing demand for water and stimulating policy by the Japanese government accelerated research activities in hydrology. The Ministry of Education set up hydrology as one of special research projects in 1967 and research funds have been prepared for it. Under this financial support, a research group was organized by about forty geographers and a variety of researches are now carrying on. This is a brief review of geographer's contributions to hydrology in Japan made after 1966. As the present writer's opinion on the system of hydrology has already expressed in the review mentioned above, the purpose of this paper is restricted only to show the current trend of hydrologic researches through published works without making any comments on them.

Books : A new text book $^{2)}$ entitled 'Terraquatic Science' was published this August as a series of earth sciences. This is the first systematic text book including all inland waters. Yamamoto, the editor of this book, writes introductory chapter as well as concluding chapter on current problems in terraquatic science. The following topics are described concisely and quantitatively: River hydraulics by M. Inokuchi, Temperature of inland waters by T. Arai, Quality of inland waters by M. Hirayama, Hydrologic cycle by I. Kayane, Water balance by M. Ichikawa, Potamology by M. Aramaki and S. Takayama, Limnology by S. Horiuchi, Geo-

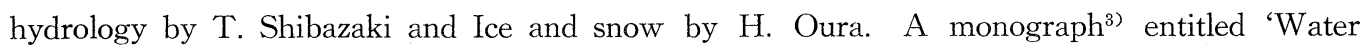
Resources Development of the National Capital Region' was also published in 1968. In this work geographers such as S. Yamamoto, M. Ichikawa, Y. Masai and K. Sawada cooperate with specialists in other academic fields such as economics, sociology and administration searching for future solution of water problems in the national capital region. 'Water Resources Handbook ${ }^{4)}$ published in 1966 is one of the most comprehensive books covering various fields in hydrology. It contains scientific, technical and developmental topics concerning water resources contributed by 35 specialists. Among them are included 6 physical geographers writing on the following titles: Groundwater by S. Yamamoto, Temperature and quality of river by T. Nishizawa, Lake and reservoir by K. Kotoda, Coastal water by M. Hirayama, Artificial rainfall by $\mathrm{M}$. Hatano and Water temperature and its regulation by $\mathrm{T}$. Arai. As for the

* Tokyo Kyoiku University.

( $\mathrm{J}$ : written in Japanese, JE : in Japanese with English summary, E : in English)

1) Yamamoto, S. (1966) : General view of hydrology in Japan. in Japanese Geography 1966, its recent trends. The Association of Japanese Geographers, Special publication No. 1, 37-42. (E)

2) Yamamoto, S. ed. (1968) : 陸水. 347 p. Kyôritsu Shuppan, Tokyo. (J)

3) Rôyama, M. and Ichinose, T. ed. (1968) : 首都圈の水資源開発. 285 p. Tokyo Daigaku Shuppankai, Tokyo. (J)

4） Aki, K. and Tada, F. ed. (1966)：水資源ハンドブック. 659 p. Asakura Shoten, Tokyo. 
book written by a single author, revised edition of 'Methods in Groundwater Prospecting' by S. Yamamoto is mentioned ${ }^{5)}$.

Water balance and water resources: It is interesting to know total amount of water taking part in hydrologic cycle either of global or regional scale. Collecting literatures concerning the amount of water, Kayane ${ }^{6)}$ compiled a table showing the amount of global waters in gaseous, liquid and solid states. The amount of groundwater is found to be the most unreliable one compared to other waters. For regional scale, the amount of groundwater can be estimated more accurately. Yamamoto ${ }^{7)}$ calculates the total amount of groundwater available in Kanto Plain to be $5 \times 10^{11} \mathrm{~m}^{3}$ which is 60 times of the present annual total of groundwater discharge pumped in the plain. Importance of studying recharge mechanism is stressed by him for evaluating groundwater as a renewable water resource. Problems of water resources are especially serious in the Inland Sea coast region where annual precipitation is relatively small $(1000$ to $1500 \mathrm{~mm})$. Takakuwa ${ }^{8)}$ describes water resources of this region based on available hydrological and meteorological data.

Studies on water balance is of practical importance especially when and where shortage in water arises. Water balance of Tama drainage basin, one of the important source regions of water for Tokyo, is calculated by Ichikawa ${ }^{9)}$. Yamamoto ${ }^{10)}$ tries to clearify water balance of Lake Ikeda, a crater lake whose water is used for irrigation. Shindo' ${ }^{11)}$ carries out water balance of unconfined groundwater in Ryôchiku Plain paying special attention to estimate lateral underground flow in relation to decrease curve of groundwater level. Effect of recharge by irrigation is also examined. To obtain more accurate estimation of individual water balance components, more accurate knowledge on scientific hydrology is required.

Potamology : To establish workable relationship between precipitation and runoff is a central task for hydrologists. This is true of geographers but with some tendency to analyse it rather than to synthesize. Comparative study of runoff from two small drainage basins having the same hydrologic characteristics except geology is conducted by Hirata ${ }^{122}$. Hydrograph analysis is applied to separate direct runoff and groundwater flow, then comparison is made between the two. Hydrograph for basin 1 which consists of shale is flatter than that of basin 2 of granite. Basin lag is longer for the former than for the latter. His conclusion is that the

5) Yamamoto, S. (1967) : 地下水探査法. 320 p. Chikyu Shuppan, Tokyo. (J)

6) Kayane, I. (1967) : Grand total of water on the earth and its rate of circulation. Suiri Kagaku, Vol. 11, 84-94. (J)

7) Yamamoto, S. (1968) : Groundwater as water resources. Toshi-mondai, Vol. 59, 52-63. (J)

8) Takakuwa, T. (1967) : Water resources of the Inland Sea coast region. Science Report of Faculty of Education, Kagawa University, Part 1, No. 21, 110-148. (J)

9) Ichikawa, M. (1968) : On the water balance and the changes in rate of flow in the Tama drainage basin, Kanto district. Tokyo Geography Papers XII, 103-120. (JE)

10) Yamamoto S.(1966) : Investigational study on land improvement project. Investigation Report of Nansatsu District in 1966, p. 21. (J)

11) Shindo, S. (1966): The analysis of hydrologic balance on unconfined ground water-with special reference to the investigation of ground water in the Ryôchiku Plain, Fukuoka Prefecture. Geogr. Rev. Japan, Vol. 39, 697-712. (JE)

12) Hirata, S. (1966) : Water-runoff from the small basins in the vicinity of Shionoe, Kagawa Prefecture. Geogr. Rev. Japan, Vol. 39, 713-729. (JE) 
coarser, deeper and more permeable soil as well as rougher river bed in basin 1 is responsible for the difference. It is interesting that the difference in two hydrographs are similar to those found between forested and non-forested drainage basin. Using a combined linear reservoir model in series and parallel, Kotoda ${ }^{13)}$ computed direct runoff for small watersheds of $322 \mathrm{~km}^{2}$ and $3.8 \mathrm{~km}^{2}$. Obtained hydrologic parameters in the model are compared with each other referring to basin characteristics. Another rainfall-runoff study conducted by Kotoda ${ }^{14}$ is for a much smaller basin of $0.96 \mathrm{~km}^{2}$. Applying hydrography analysis, initial losses are obtained to be 0.5 to $6.5 \mathrm{~mm}$ with close relation to initial runoff height and effective runoff coefficients are calculated to be about 55 to $65 \%$.

Snow-melting runoff is surveyed by Arai et $\mathrm{al}^{15)}$ in a drainage basin with heavy snow. Snow survey, heat budget and hydrologic observations are made together with aerial photograph analysis on accumulated snow depth. As a result, possibility of utilizing aerial photograph for estimating areal snow accumulation is suggested. Heat budget study on the snow reveals the important role of insolation to produce snow-melt runoff. Net runoff ratio is about $60 \%$ during the snow-melt season indicating unexpectedly large water loss by evaporation. On winter base flow is taken climatological-hydrological approach by Arai ${ }^{16)}$. Noticing that winter base flow is greater in snow accumulated regions than in regions without snow, he tries to interprete this by considering heat supply from the soil to snow. The amount of heat supplied from the soil is calculated to be about $10 \mathrm{ly} /$ day.

A series of geochemical investigations of river and spring waters are made by Kato ${ }^{17)-21)}$ concerning dissolved minerals and suspension. Quantitative relation between flow rate $(Q)$ and mineral discharge $\left(Q_{d}\right)$ is expressed in general by the equation $Q_{d}=a Q^{n}$ where $a$ and $n$ are constants. Total amounts of dissolved and suspended materials transported by rivers are calculated for some drainage basin. As for bed load movement, Takayama's field experiment in the three rivulets is reported ${ }^{22}$. The relation between the shape of gravel particles and their

13) Kotoda, K. (1967) : Preliminary study of rainfall-runoff relation in the natural basin. Tokyo Geography Papers XI, 257-268. (JE)

14) Kotoda, K. (1968) : Field study on rainfall-runoff relations in a small basin-initial loss and runoff coefficient-. Tokyo Geography Papers XII, 121-142. (JE)

15) Arai, T., Nishizawa, T. and Kotoda, K. (1967): On the snow cover and snow-melting runoff in the Takinami river basin, Central Japan. Geogr. Rev. Japan, Vol. 40, 426-444. (JE)

16) Arai, T. (1968) : Climatological-hydrological consideration on winter runoff. Geogr. Rev. Japan, Vol. 41, 393-394. (J)

17) Kato, T. (1966) : A geochemical investigation of the Harai-gawa River, Zaô district. Jour. Limnol. Vol. 27, 16-24. (JE)

18) (1966) : Geochemical investigations on the springs at the western foot of Zaô and Ryû-zan volcanoes. Jour. Limnol. Vol. 27, 95-106. (JE)

19) (1966): The variation of the quality-of-water of the Tachiya-gawa River during the season of rapid thaws. Jour. Limnol. Vol. 27, 142-154. (JE)

20) (1968): Hydrological studies on the quality-of-water and the transportation of dissolved minerals and suspension of the Mamigasami-gawa River, Yamagata City. Jour. Limnol. Vol. 29, 3751. (JE)

21) (1968) : Hydrological investigations of the Takase River, Yamagata City. Annals, Tohoku Geogr. Assoc. Vol. 20, 27-33. (JE)

22) Takayama, S. (1966) : Bed load movement in mountain streams (2). Tokyo Geography Papers X, 113-126. (JE) 
transported distance is obtained. On river water temperature, Nishizawa ${ }^{23)-25)}$ is mostly concerned with heat exchange arised from inflowing waters such as springs, tributaries and so on.

In the field of estuary hydrology are studied sea water intrusion near the river mouth. Using Farmar and Morgan's equation Hara ${ }^{26)}$ calculates the maximum length of salt wedges in the river flowing into Tokyo Bay. Obtained length is very large for larger rivers and correction is made taking the gradient of river bed into account. Salinity observations are made in the Yoneshiro River by Mitsui et $\mathrm{al}^{27)}$ and the river is classified as fine negligible mixing type concerning the salt wedge. The salt wedge length is generally short but it reaches to 6 $\mathrm{km}$ upstream from the river mouth when runoff rate decrease to $40 \mathrm{~m}^{3} / \mathrm{sec}$.

Limnology : One of serious problems pertaining to artificial reservoir is gradual loss of storage capacity caused by the deposition of sediments. Takayama ${ }^{28)}$ calculates the volume of sediment accumulated in Yakuwa reservoir to be $418 \mathrm{~m}^{3} / \mathrm{km}^{2} / \mathrm{yr}$. The relation of this sediment volume to such factors as $\mathrm{C} / \mathrm{F}$ ratio, $\mathrm{C} / \mathrm{I}$ ratio, topographic index and so on are tested and found to be close agreement with the empirical formulae proposed by many researchers. Investigation on bottom topography and size distribution of sediment materials reveals that appreciable quantity of sediment might have been transported during floods in the snow melting season. Dividing total capacity by annual sediment accumulation, the life of this reservoir is calculated to be 81 years. According to Inokuchi's study ${ }^{29)}$, the total volume of sediment deposited in Sagami reservoir during 15 years after completion is $5 \times 10^{6} \mathrm{~m}^{3}$. This amounts to one tenth of the total capacity of the reservoir. The deposited sediments are mostly composed of coarse materials such as sand and gravel and these materials make up a delta. Process of the delta development is discussed based on observations on tractive force of flowing water.

Thermal stratification of artificial reservoirs is intensively studied by Arai ${ }^{30), 31)}$. According to him, water temperature characteristics of artificial reservoirs are classified into two groups depending on the ratios of water area to runoff or water volume to storage. Thermal stratification develops in one group of reservoirs but it does not in the other. Based on the heat budget calculation of typical reservoirs for each group, he clearifies the forming process of

23) Nishizawa, T. (1966) : On river water temperature. Tokyo Geography Papers X, 127-136. (JE)

24) (1966): The heat balance of river water-with special regards to the effects of tributaries and spring water-. Tokyo Geography Papers X, 137-148. (JE)

25) (1967) : River water temperature in Japan. Miscellaneous Rept. Research Inst. for Natural Resources, No.68. 54-61. (E)

26) Hara, A. (1967) : The upper limit of the intrusion of sea water in the rivers flowing into Tokyo Bay. Jour. Geogr. Rev. Vol. 40, 251-260. (JE)

27) Mitsui, K., Totani, Y., Inoue, T. and Teranishi, T. (1967) : On the salt intrusion in the river Yoneshiro, Akita Prefecture. Miscellaneous Rept. Research Inst. for Natural Resources, No.68, 21-30. (JE)

28). Takayama, S. (1967) : Sedimentation in the Yakuwa Reservoir, Yamagata Prefecture. Miscellaneous Rept. Research Inst. for Natural Resources. No. 69. 34-45. (JE)

29) Inokuchi, M. (1967) : Delta development in Sagami reservoir. Tokyo Geography Papers XI, $207-226$. (JE)

30) Arai, T. (1967) : On the thermal structure of the Tagokura reservoir (second report). Jour. Geogr. Rev. Vol. 40, 476-487. (JE)

31) Arai, T. (1967) : Heat budget studies on the water temperature of the artificial reservoirs (part 1 , part 2). Miscellaneous Rept. Research Inst. for Natural Resources, No. 68, 31-54, No.69, 6-22. (E) 
water temperature and evaluates the important role of advected heat on thermal stratification. For a small lake having uniform vertical temperature distribution, chemical stratification is reported by $\mathrm{Ambe}^{32)}$. The lake is located at a sea coast and wind driven sea salt is thought to contribute to form the surface layer. A series of limnological investigations are conducted by $\mathrm{Kato}^{33)-36)}$ on the lakes in Tohoku district.

Geohydrology : Reflecting hydrologic, topographic and geologic conditions, occurrence of groundwaters are different from place to place. Generalization is in most cases difficult and this makes the following regional studies on groundwater indispensable. Groundwaters in alluvial $\mathrm{fan}^{37)}$, terrace ${ }^{38)}$, alluvial plain ${ }^{39)}$ and hilly region ${ }^{40)}$ are investigated. Groundwater flow pattern, seasonal fluctuation of water level, relation between water table configuration and hydrogeologic structure are the main concerns for these investigators. Among these papers, Hosono's elaborate study on groundwater in Musashino terrace is worthy of note. He constructed detailed contour maps of unconfined groundwater table using data of more than 3000 wells. During his investigation it happened groundwater pollution with gasoline in a series of wells. Judging from his water table map, he concludes that the source of the gasoline is in the Tachikawa air base because polluted wells are located in a groundwater valley originated from the air base. This shows one example of practical importance of this kind of study. Retreat of the self-flowing zone of artesian wells is investigated in Ichihara district by Taguchi et $\mathrm{al}^{41}$. With increasing number of deeper industrial wells in the coastal zone after 1958, artesian wells inclusively for agricultural or domestic use stopped self-flowing and non-flowing area expanded inland. The pattern of industrialization and that of non-flowing area are closely correlated by them. Shindo ${ }^{42)}$ make detailed study on confined groundwater in Musashino terrace from the hydrogeological point of view.

A step forward to generalization of water table configuration is made by Iwashita ${ }^{43)}$. She

32) Ambe, Y. (1967) : Chemical stratification of the water of Lake Inogaike, Fukui Prefecture. Geogr. Rept. Tokyo Metropol. Univ. Vol. 2, 143-146. (E)

33) Kato, T. (1966) : A limnological investigation of the crater lake 'Goshiki-numa' of Mt. Issaikyô, Fukushima prefecture. Jour. Limnol. Vol. 27, 40-47. (JE)

34) (1967) : Limnological investigations of Lake Nabekoshi-numa, Yamagata Prefecture. Jour. Limnol. Vol. 28, 1-11. (JE)

35) Kato, T. and Aita, N. : Limnological investigations of Lake Yozô-numa, Yamagata Prefecture. Jour. Limnol. Vol. 28, 124-131. (JE)

36) Kato, T. and Shida, I. (1966) : Morphometrical and hydrochemical investigations of the lakes in the vicinity of Zaô spa. Annals, Tohoku Geogr. Assoc. Vol. 18, 70-74. (JE)

37) Tsukada, K. (1968): On the fluctuations of groundwater level in Nasunogahara. Geogr. Rev. Japan, Vol. 41, 390-391. (J)

「Vol. 41, 391. (J)

38) Hosono, Y. (1968) : On the unconfined groundwater in Musashino terrace. Geogr. Rev. Japan,

39) Watanabe, T. (1967) : Unconfined groundwater in the alluvial low land on the left side of the Sagami River. Hydrology, No. 1, 21-23. (J)

40) Ishikawa, Y., Takayama, S., Takamura, H. and Sekine, K. (1968) : On the groundwater in the Ôgurigawa drainage basin, Tama hills. Geogr. Rev. Japan, Vol. 41, 394. (J)

41) Taguchi, Y., Tanaka T. and Yokoyama, N. (1968): Retreat of self-flowing zone of groundwater in Ichihara district, Chiba Prefecture. Chiri, Vol. 13, 142-144. (J)

42) Fujimoto, H. and Shindo, S. (1966) : Hydrogeology of the Musashino terrace (II). Science Rept. of Toyo Univ., Faculty of Engineering, No.2, 31-62. (JE)

43) Iwashita, S. (1967) : Relationship between unconfined groundwater table and ground surface on longitudinal profiles of fans. Hydrology, No. 1, 24-26. (J) 
constructed longitudinal profiles of the groundwater table for 47 alluvial fans and tested whether the water table is parallel to the surface or not. According to her classification, frequency of parallel, non-parallel, median, and complex-type are $63 \%, 15 \%, 15 \%$ and $7 \%$ respectively. Parallel type is found in shallow water table fans and non-parallel type in deeper water table fans. Another trial for quantitative expression of groundwater table configuration is made by Fukuda $^{44)}$. Applying the theory of log-normal-probability distribution, he tries to obtain a equation showing relationship between the water table depth and its corresponding area. His conclusion is that the equation is applicable to obtain depth-area curve of groundwater table. Relation between the rain and the water table rise is investigated by Hirata ${ }^{45)}$ for unconfined ground-water in a terrace. Influence function is obtained by fourier analysis for water table fluctuations and rainfall records. It is found that the influence of rainfall 8 days before appears most prominently on the water table fluctuation.

Kiuchi and Iwashita ${ }^{46)}$ investigates the distribution of chlorine content in the groundwater in the lower basin of the Tone River and find that wells of high chlorine content are within band-like zones. The direction of the band zones does not show any correlation with present landform but coincides with the direction of fossil valley. Judging from land history of this area, the age of this fossil groundwater is estimated to be 10 to 15 thousand years. Electric conductivity of groundwater in a sandy region is studied by Takamura ${ }^{47}$ with the purpose to utilize it for flow pattern investigation.

Water pollution: In hydrology, pollution of water is one of the most distinguished phenomena which are influenced by human activity. According to Hanya and Ambe ${ }^{48)}$, the total amount of organic wastes is estimated to be 7 to 12 million tons in COD and that of waste water to be 20 billion tons excluding sea water in Japan. Unsuitability of present water system of Japan for these great quantity of wastes is pointed out and a proposal for future water system which will prevent pollution of river water is made by them. Chemical properties of organic contents in polluted waters of five rivers in Tokyo is analyzed by spot test method by Ambe et al $^{49) 50)}$. The quality of water of each river are related to the type of pollution reflecting the environmental characters of the river. The water quality of the Agazuma River, famous for its poisonous acid water, was artificially changed by neutralization with limestone

44) Fukuda, K. (1968): On the theoretical equation showing the relationship between the water-table depth and its corresponding area for a given period. Jour. Japanese Assoc. Groundwater Hydrology,
No. 14, 4-10. (E)

45) Hirata, S. (1967) : Fluctuation of groundwater level at Hakusan, Hongo terrace, Tokyo. Hydrology, No. $1,13-15 .(\mathrm{J})$

46) Kiuchi, S. and Iwashita, S. (1968): The distribution of chlorine content in the groundwater in the lower basin of the Tone River, concerning Omigawa, Sawara and Kashima districts. Geogr. Rev. Japan, Vol. 41, 450-460. (JE)

47) Takamura, H. (1967): On the electric conductivity of groundwater-a case study in the sandy region along Kashimanada coast--. Suion no Kenkyu, Vol. 10, 15-19. (J)

48) Hanya, T. and Ambe, Y. (1967) : Estimation of total amount of organic wastes and a proposal for the future water system in Japan. Water Pollution Research, 4, 88-92. (E)

49) Ambe, Y, and Hanya T. (1967) : A classification of the types of industrial waste waters according to the chemical properties analyzed by spot test method. Water pollution Research, 4, 59-67. (JE)

50) Ambe, Y. and Hanya, T. (1967): Application of spot test for the organic analysis of polluted river waters in Tokyo. Water Pollution Research, 4, 68-75. (JE) 
after 1964. Mitsui et $\mathrm{al}^{51)}$ are investigating influences of this change in water quality from acid to alkaline on water quality and biological activities in the lower course of this river. Water pollution in the lower reaches of the Jintsu River is investigated by Yamamoto et $\mathrm{a}^{52}{ }^{52}$ in order to clearify how changes in river bed profile caused by artificial gravel mining affects diffusion process of industrial waste water from a factory.

Socio-economic hydrology : Though Japan is thought to be abundant in water resources, shortage in water occurs in some areas and conflict over water use between irrigation, water power and industry is increasing. In this respect socio-economic approach is of great importance. Ishii ${ }^{53)}$ attempts to investigate the socio-economic structure for water use in transition, through an analysis of the process of contact, negociation and compromise between water power development and irrigation system in a river basin. Moritaki ${ }^{54}$ make an appraisal of socioeconomic studies of water resources problem in the field of geography, and tries to classify $y^{55}$ Japanese rivers according to types of socio-economic relations on the use of their water. $\mathrm{He}$ also investigates ${ }^{56}$ areal distribution of the dams for power plants and clarifies how the movement of capital in the electric-power-generating industry is reflected upon it. As for groundwater use, Hida ${ }^{57)}$ investigates development process of industrial water in Gakunan district where initially abundant groundwater is impaired by sea water intrusion caused by over pumping and newly constructed inland port. The process of sea water intrusion in this area is briefly discussed by Okabe et $\mathrm{al}^{58)}$. Horiuchi investigates ${ }^{59)}$ the problem on the irrigation structure of the villages in Nara basin and tries to clearify the characters of the villages and their regionalities. He also investigated historical development process of irrigation in Kinokawa Plain to clear up regional characteristics ${ }^{60}$. Relation between poisonous acid water and agriculture in Shimokita Peninsula is discussed by Mitsui ${ }^{61)}$.

New techniques: By introducing radio-isotope techniques in hydrology new research fields

51) Mitsui, K. and Inoue, T. (1966) : On the changes of chemical properties of the Agazuma River, a tributary of the Tone River (Preliminary report). Miscellaneous Rept. Research Inst. for Natural Resources, No. 67, 17-25. (JE)

52) Yamamoto, S., Ichikawa, M., Hara, A., Tsukada, K. and Watanabe, T. (1968): Water pollution in the lower reaches of the Jintsu River. Jour. Geogr. Rev. Vol. 41, 395. (J)

53) Ishii, M. (1967) : Relations of water-power development to irrigation system-a case study in the Kuzuryu-River basin-. Sundai-shigaku, No. 21, 1-13. (JE)

54) Moritaki, K. (1966) : An appraisal of socio-economic studies of the water resources problem in the field of geography. Annals, Assoc. Economic Geogr. Vol. 12, 1-16. (JE)

55) Moritaki, K. (1966) : Social relations on the use of river water. Geogr. Rev. Japan, Vol. 39, 757-786. $(\mathrm{JE})$

56) (1966): Areal distribution of the dams for power plants. Annals, Assoc. Economic Geogr. Vol. 12, 51-69. (JE)

57) Hida, N. (1968): The situation of groundwater use for industry in Gakunan district, Shizuoka Prefecture. M.S. Thesis of Tokyo Kyoiku Univ. (To be published).

58) Okabe, F., Kadowaki, K. and Maruta, H. (1968): The salt water encroachment of the groundwater in the vicinity of port of Tagonoura, Shizuoka Prefecture, Central Japan. Geogr. Rev. Japan, Vol. 41, 201-206. (J)

59) Horiuchi, Y. (1966) : A study on the irrigation structure of the villages in the Nara basin. Geogr. Rev. Japan, Vol. 39, 159-167. (JE)

60) (1967): Study of the irrigation system in the Kinokawa Plain. Geogr. Rev. Japan, Vol. 40, 663-678. (JE)

61) Mitsui, K. (1967) : Poisonous acid water and agriculture in Shimokita Peninsula. Jinrui-Kagaku, No. 18, 124-134. (J) 
are expanded. One example is neutron meter by which soil moisture can be measured repeatedly without destroying soil profile. Calibration technique for our instrument is reported by Yamamoto et $\mathrm{al}^{62)}$. By using this instrument $\mathrm{S}$. Hirata carried out one year's soil moisture measurement for a vertical profile from the surface to the depth of 12 meters where groundwater table exists. Another technique adapted by us is the tritium analysis for tracing groundwater movement. Great amount of tritium produced by thermo-neuclear explosion has been supplied to hydrologic circulation after 1954. By measuring tritium content in groundwater, therefore, we may know whether the groundwater has infiltrated before 1954 or later. K. Tsukada is making a research on tracing groundwater in a simply structured artesian basin by this method.

(1968 年 9 月 12 日 受理)

62) Yamamoto, S., Kayane, I. and Hirata, S. (1968) : Calibration of neutron soil moisture meter. Tokyo Geography Papers, XII, 85-101. (JE) 